\title{
$\mathrm{BeAl}_{2} \mathrm{O}_{4}$ 添加窒化ケイ素の HIP 焼結
}

\author{
吉田晴男・条 正市・町田充秀 \\ (名古屋工業技術試験所)
}

\section{HIPing of Silicon Nitride with Additive of $\mathrm{BeAl}_{2} \mathrm{O}_{4}$}

\author{
Haruo YOSHIDA, Shoichi KUME and Michihide MACHIDA \\ $\left(\begin{array}{l}\text { Government Industrial Research Institute, Nagoya } \\ \text { 1-1, Hirate-cho, Kita-ku, Nagoya-shi } 462\end{array}\right)$
}

Silicon nitride with a small amount of additive $\mathrm{BeAl}_{2} \mathrm{O}_{4}$ was sintered by HIP treatment in glass capsules. The sintered body of $\mathrm{Si}_{3} \mathrm{~N}_{4}$ was for the most part $\beta$ phase. BeAl $\mathrm{O}_{4}$ dissolved into $\beta$-Si $\mathrm{N}_{3} \mathrm{~N}_{4}$ completely. The effect of isostatic pressure was significant in HIP sintering. For example, the bulk density of sintered body containing 3 wt\% $\mathrm{BeAl}_{2} \mathrm{O}_{4}$ was almost theoretical, and its microstructure was homogenous when sintered above $1700^{\circ} \mathrm{C}$ and at an applied pressure $200 \mathrm{MPa}$.

Key-words : Hot isostatic pressing, Silicon nitride, Sintering

[Received December 5, 1985]

\section{1. 緒言}

窒化ケイ素 $\left(\mathrm{Si}_{3} \mathrm{~N}_{4}\right)$ は難焼結性物質であるため, 焼 結助剤を加えて焼結させるのが一般的である. 助剤とし て, 高温で液相を生ずる物質を用いる場合が多いが, 心゙ リリウムアルミネート $\left(\mathrm{BeAl}_{2} \mathrm{O}_{4}\right)$ の場合は $\beta-\mathrm{Si}_{3} \mathrm{~N}_{4}$ と 固溶関係にあることを利用した焼結助剤であるので1), 焼結体粒界にガラス質等の第 2 相を作らず, 高温で高強 度が予想される。

一方, ガラスカプセルを用いた, $\mathrm{Si}_{3} \mathrm{~N}_{4}$ の熱間等方加 圧 (HIP) 焼結法は, 高い等方圧力の効果により, 常圧 焼結法やホットプレス法に比べ少量の焼結助剤でよく, また等方的で均一な組織が実現できる.

本研究は, $\mathrm{Si}_{3} \mathrm{~N}_{4}$ に焼結助剂として $\mathrm{BeAl}_{2} \mathrm{O}_{4}$ を少量添 加し, ガラスカプセルを用いた HIP 法により, その焼 結について検討したものである.

\section{2. 実 験}

$\mathrm{Si}_{3} \mathrm{~N}_{4}$ 原料には, 不純物の比較的少ない Hermann C. Starck 製 $\mathrm{H} 1 \mathrm{~B}$ を用いた。 $\mathrm{BeAl}_{2} \mathrm{O}_{4}$ (平均粒径 $0.92 \mu \mathrm{m}$ ) を 3, 5, $10 \mathrm{wt} \%$ 添加し, ヘキサン中で 4 時間振動ミル による混合を行い, 真空乾燥して出発原料とした. なお, 比較のために助剤無添加の試料も用意した。約 2 グラム の粉末を $30 \mathrm{MPa}$ で円板状 ( $\phi 19.5 \mathrm{~mm} \times t 4 \mathrm{~mm})$ に金 型成形した後, $200 \mathrm{MPa}$ で静水圧成形し試料とした。

カプセル材には, パイレックスガラスを用いた.また， ガラスカプセルと試料との反応を防ぐために, $1000^{\circ} \mathrm{C}$, 2 時間真空処理した BN で試料を包んだ. カプセル内の $\mathrm{BN}$ 及び試料は $400^{\circ} \mathrm{C}, 12$ 時間真空脱気し, その後真空 封入した. HIP 焼結は, これらのカプセルを $\mathrm{BN}$ で満
たしたグラファイトるつぼに入れて行った. HIP 処理 の圧力媒体ガスとして Ar を用いた。

HIP 処理スケジュールと条件を図 1 及び表 1 に示す. ガラスカプセルは, 軟化する前に, 圧力により破損する ことがあるので, 初期圧力を $1 \mathrm{MPa}$ 以下に保ち昇温を 先行させた。なお，ブースターによる昇圧時間は約 40

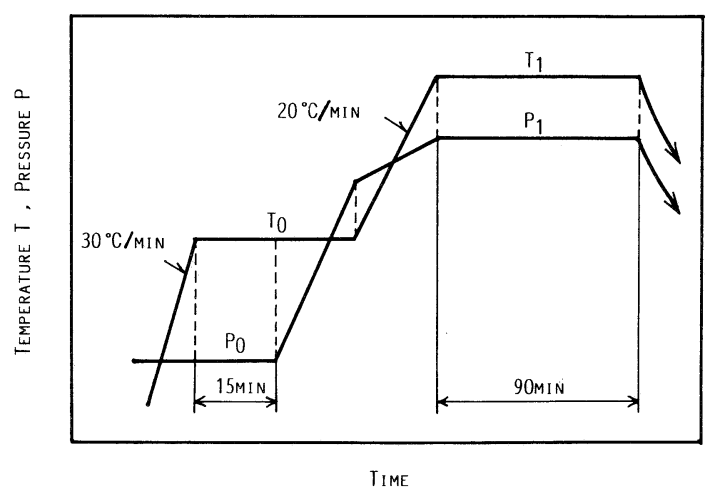

Fig. 1. Schedule of HIP treatment.

Table 1. Conditions of HIP treatment.

\begin{tabular}{|l|}
\hline$P_{0} \lesssim 1 \quad M P_{A}$ \\
$P_{1}=200$ \\
\hline$T_{0}=900{ }^{\circ} \mathrm{C}$ \\
$T_{1}=1700$ \\
1800 \\
1900
\end{tabular}




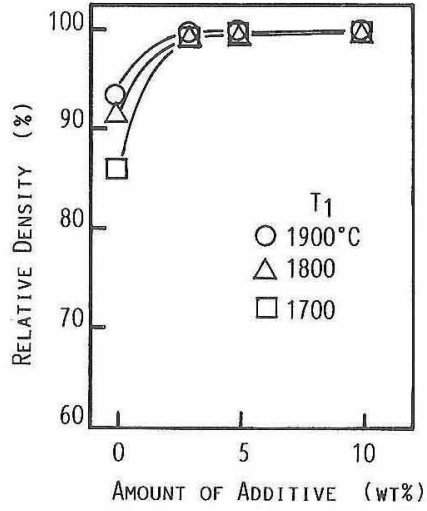

Fig. 2. Relative density of the $\mathrm{Si}_{3} \mathrm{~N}_{4}$ sintered by HIPing.

\section{〜60分であった.}

得られた焼結体は密度測定及び微小硬度の測定 (Nikon 製 QM 型装置)，破面の微組織観察（明石製作 所製 ISI 100 走査型電子顕微鏡）を行った。また，結晶 相は焼結体を粉砕して, 粉末X線回折により調べた。

\section{3. 結果と考察}

HIP 処理により，カプセル材のがラスが BN を通し て試料に侵入することが問題になるが，得られた被処理 体は目視，硬度及び密度の点においても，ガラスが侵入 したものとは明らかな違いがあり，BNにより完全に遥 ヘいされたものと思われる。

$\mathrm{X}$ 線回折の結果, 助剂 $3 \mathrm{wt} \%$ 添加の $1700^{\circ} \mathrm{C}$ の焼結体 では，鈴木らの $\alpha$ 相分率定量法 ${ }^{1}$ で約 $20.6 \%$ の- $\mathrm{Si}_{3} \mathrm{~N}_{4}$ が認められた．そのほかの助剤添加の焼結体ではすべて $\beta$ 相であった。一方，焼結助剂 $\mathrm{BeAl}_{2} \mathrm{O}_{4}$ の回折ピーク はいずれの試料においても認められず， $\beta-\mathrm{Si}_{3} \mathrm{~N}_{4}$ へ完全 に固溶したものと思われる。また，焼結助剂 $3 \mathrm{wt} \%$ 添 加の焼結体のすべてにのみ，わずかであるが $\mathrm{Si}_{2} \mathrm{~N}_{2} \mathrm{O} の$ 回折ピークが認められた。これらは焼結温度が低いほど 相対的に大きくなる傾向にあった。

図 2 に相対密度を示す. $\mathrm{BeAl}_{2} \mathrm{O}_{4}$ を添加した $\mathrm{Si}_{3} \mathrm{~N}_{4}$ の

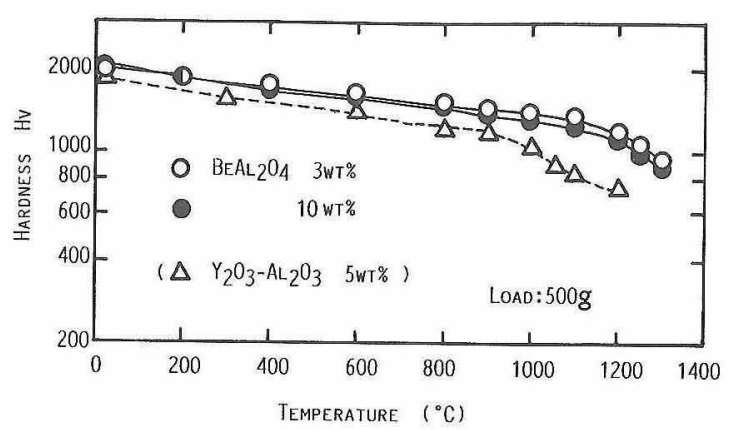

Fig. 3. Temperature dependence of hardness $H_{\mathrm{v}}$ for the samples sintered at $T_{1}=1800^{\circ} \mathrm{C}$.

相対密度は，いずれも $99 \%$ 以上あり，3 wt \% 添加では 焼結温度 $1900^{\circ} \mathrm{C}$ で， 5 wt\%では $1800^{\circ} \mathrm{C}$ ，そして 10 $\mathrm{wt} \%$ では $1700^{\circ} \mathrm{C}$ でほとんど理論密度になった。常圧焼 結の報告と比較すると，少量の $\mathrm{BeAl}_{2} \mathrm{O}_{3}$ 添加ではるかに ち密になっており，等方加圧の効果が極めて著しい.

図 3 に, 微小ビッカース硬度の温度依存性を示す. 比 較のために, $\mathrm{Y}_{2} \mathrm{O}_{3}-\mathrm{Al}_{2} \mathrm{O}_{3}$ (重量比 $1: 2$ ) を添加し，同 じ HIP 焼結を行ったものを示す. $\mathrm{BeAl}_{2} \mathrm{O}_{4}$ を添加した 試料の硬度は，室温で 2000 前後あり， $1300^{\circ} \mathrm{C}$ まで のすべての温度でも $\mathrm{Y}_{2} \mathrm{O}_{3}-\mathrm{Al}_{2} \mathrm{O}_{3}$ 添加のそれより高く， また $900^{\circ} \mathrm{C}$ 付近の硬度の急激な低下はなかった。しか し， $3 \mathrm{wt} \%$ と $10 \mathrm{wt} \%$ 添加では高温での硬度にやや差が あることや，X 線回折で $\mathrm{Si}_{2} \mathrm{~N}_{2} \mathrm{O}$ ピークが認められるこ とから，多少は粒畨相が存在するものと考允られる。

図 4 は，焼結温度 $1800^{\circ} \mathrm{C}$ の焼結体破面である。いず れも粒内破壊を起こしており，極めて良好に焼結してい る. 3 wt \% 及び $5 w t \%$ 添加の試料では気孔が見受けら れたが，10wt％では認められなかった。

今後, $\mathrm{Si}_{3} \mathrm{~N}_{4} に \mathrm{BeAl}_{2} \mathrm{O}_{4}$ を微量添加した場合の, HIP 法における焼結挙動を更に詳しく調べる必要があるう。

\section{文 献}

1）神崎修三, 由端英世, 高田忠信, 第 22 回窯業基礎討論会 講演要旨集 (1984) p. 35 .

2）鈴木和夫，管野善則，䇥協，92，101-02 (1984).
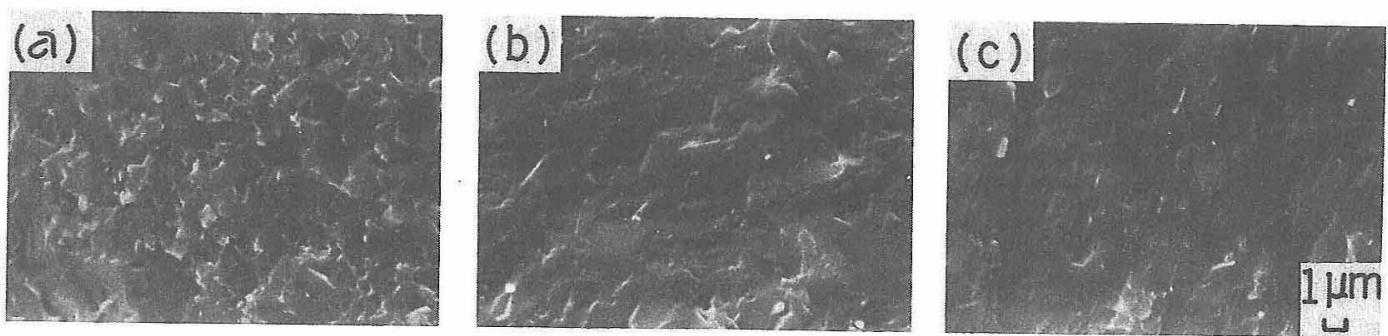

Fig. 4. Fractured surfaces of samples HIPed at $T_{1}=1800^{\circ} \mathrm{C}$. Amount of $\mathrm{BeAl}_{2} \mathrm{O}_{4}$ additive: (a) $3 \mathrm{wt} \%$, (b) $5 \mathrm{wt} \%$, (c) $10 \mathrm{wt} \%$. 